\title{
TRENDS AND PROSPECTS FOR LEGISLATIVE REGULATION OF LEGAL RESPONSIBILITY FOR ENVIRONMENTAL OFFENSES IN BRICS COUNTRIES: COMPARATIVE LAW
}

\author{
ALEKSEY ANISIMOV, \\ Volgograd Institute of Management - Branch of the Russian Academy of National Economy \\ and Public Administration under the President of the Russian Federation \\ (Volgograd, Russia) \\ JULIA KAYUSHNIKOVA, \\ Volgograd Institute of Management - Branch of the Russian Academy of National Economy \\ and Public Administration under the President of the Russian Federation \\ (Volgograd, Russia)
}

DOI: $10.21684 / 2412-2343-2018-6-1-82-101$

This article provides a comparative analysis of the features of the national legislation of the BRICS countries that regulates the issues of legal responsibility for environmental offenses. The authors consider aspects of the normative consolidation of the rights and obligations of citizens in the field of environmental protection, the types of legal liability and the applicable sanctions for violations of environmental standards provided for by the national legislation of all BRICS countries. The study of the environmental legislation of the BRICS countries (Brazil, Russia, India, China and South Africa) reveals a number of general and specific directions in environmental policy with the aim of enriching the said countries with positive experience, overcoming difficulties in the organization of environmental management and environmental protection, the prevention of possible errors in the context of global economic and environmental crises, and making recommendations for environmental improvement.

Improving the legislation of the BRICS countries in the field of legal liability for environmental offenses by taking into account the positive experience of these countries will help increase the effectiveness of prevention and rectification of negative consequences for the environment in both the Russian Federation and the BRICS association as a whole. Consequently, a comparative legal analysis of national environmental legislation of BRICS countries suggests that the general principles of 
responsibility for environmental offenses are inherent in all these countries, despite their fundamental differences in history, culture and geographical location.

Keywords: BRICS; environmental rights; environmental responsibilities; environmental legislation; responsibility; environmental protection.

Recommended citation: Aleksey Anisimov \& Julia Kayushnikova, Trends and Prospects for Legislative Regulation of Legal Responsibility for Environmental Offenses in BRICS Countries: Comparative Law, 6(1) BRICS Law Journal 82-101 (2019).

\section{Table of Contents}

\section{Introduction}

\section{Peculiarities of the Legislation of the BRICS Countries on Legal Liability for Environmental Offenses}

1.1. Federative Republic of Brazil

\subsection{Republic of India}

1.3. People's Republic of China

\subsection{Republic of South Africa}

1.5. Legal Regulation of Legal Responsibility for Environmental Law Violations in the Russian Federation

2. Suggestions for Improving Legal Responsibility for Environmental Offenses in the Context of the BRICS Experience

\section{Conclusion}

\section{Introduction}

BRICS is an association of five countries, the Federative Republic of Brazil, the Russian Federation, the Republic of India, the People's Republic of China and the Republic of South Africa. Each of the member countries of the association has its own unique legal features and environmental legislation due to the mentality of the population and the level and nature of social, economic and legal development.' These factors affect the goals and the methods of the arrangement of land, mineral resources,

\footnotetext{
Ушаков И.В. Укрепление международно-политических позиций России в контексте экологической дипломатии в рамках БРИКС и китайский фактор // Стратегия России в БРИКС: цели и инструменты: Сборник статей [Igor V. Ushakov, Strengthening the International Political Positions of Russia in the Context of Environmental Diplomacy of the BRICS Countries and the China Factor in Russia's Strategy Within BRICS: Aims and Instruments: Collection of Articles] 402 (V.A. Nikonov \& G.D. Toloraya (eds.), Moscow: RUDN, 2013).
} 
forest plantations and other natural resources, as well as the attitude of society to them. This is most clearly manifested in relation to legal responsibility. Currently, the punishments imposed for committing environmental offenses in BRICS countries differ significantly. In some, emphasis may be placed on criminal law sanctions, in others, on a combination of administrative and civil responsibility. In academic literature, BRICS is described as international quasi-organization ${ }^{2}$ or an "informal club."

According to O. Meshcheryakova, this is due to the fact that BRICS cannot be called an integrated community in the full sense of the word: the countries of the association are located in different parts of the planet, their national interests vary significantly, and they have different currencies. ${ }^{4}$ V. Lukov qualified BRICS as an "alliance of reformers," bearing in mind the general focus on reorganizing the system of key international institutions (primarily financial and economic). ${ }^{5}$ The important elements of the organizational unity of the BRICS association are the tools that ensure an equivalent exchange of resources between interested states. ${ }^{6}$

The creation of alternative centers of the world system is a key aim of the transformation of the modern world order. The transcontinental BRICS union combines, along with other factors, their ecological uniqueness at the global inter-mainland level: together, Russia and Brazil account for $40 \%$ of the world's forest land, and have a decisive impact on the production of oxygen and the climate of the planet.'

As P. Catalano pointed out, the BRICS countries are together responding to modern challenges (e.g. territorial expansion, demographics and economic stability); this is facilitated by the legal history of large spaces with a continuity of at least two real empires, i.e. the Middle Empire (China) and the Roman Empire, as well

2 Абашидзе А.Х., Солнцев А.М. БРИКС - международная квазиорганизация? // Актуализация процесса взаимодействия стран БРИКС в экономике, политике, праве: Материалы научного семинара [Aslan K. Abashidze \& Alexander M. Solntsev, BRICS - International Quasi-Organization? in Updating the Process of Interaction of the BRICS Countries in Economy, Politics, and Law: Materials of a Scientific Seminar] 14 (K.M. Belikova (ed.), Moscow: Senat Press, 2012).

3 Кузнецов А.В. Транснациональные корпорации стран БРИКС // Мировая экономика и международные отношения. 2012. № 3. С. 3-4 [Alexey V. Kuznetsov, Transnational Corporations of the BRICS Countries, 3 World Economy and International Relations 3, 3-4 (2012)].

4 Мещерякова О.М. Фрагментация как основной фактор, определяющий развитие интеграционных процессов // Актуализация процесса взаимодействия стран БРИКС в экономике, политике, праве: Материалы научного семинара. С. 91-94 [Olga M. Meshcheryakova, Fragmentation as a Main Factor Determining Integrative Processes in Updating the Process of Interaction of the BRICS Countries in Economy, Politics, and Law, supra note 2, at 91].

5 Луков В.В. БРИКС - фактор глобального значения // Международная жизнь. 2011. № 6. С. 32-33 [Vadim V. Lukov, BRICS - a Factor of Global Importance, 6 International Life 30, 32-33 (2011)].

6 Аналитический доклад «Россия в БРИКС. Стратегические цели и средства их достижения» [Analytical report "Russia in BRICS. Strategic Goals and Means of Achieving Them"] 24 (Moscow, 2013).

Акопян О.А. и др. БРИКС: контуры многополярного мира: Монография [Olga A. Akopyan et al., BRICS: The Contours of the Multipolar World:Monograph] (T.Ya. Khabrieva (ed.), Moscow: Institute of Legislation and Comparative Law under the Government of the Russian Federation; Yurisprudentsiya, 2015). 
as the "Third Rome" in the East (Russia) and the a fifth empire in the West (Brazil). The position of N. Bevelikova is worth supporting; she believed that the need for a dialogue to establish legal interaction between countries that are major centers of influence in their regions (Russia in the Eurasian Union and the SCO, China in ASEAN, and Brazil in MERCOSUR and (ELAC) is dictated by the intensity of ongoing integration processes in the globalizing world, and the evident activity of BRICS is a distinctive feature of its dynamic formation. Under these conditions, the BRICS association is a new algorithm of international relations that is being built without stereotypes - as a global platform with its own development vector. ${ }^{9}$

Therefore, the BRICS association is presently an integration structure of a completely new type, differing both from regional alliances (ASEAN, APEC, the EU, NAFTA, and SCO) and from the interregional organization ASEM (Asia-Europe Meeting), which includes countries from Eastern Asia and Western Europe. The creation of numerous interstate associations (EEU, SCO, BRICS, etc.), along with economic, political, and military endeavors, as well as environmental ones, designed to balance world, intercontinental, national ecological contradictions and conflicts arising from of the opposition between economics and ecology, which have one phonetic root, but are in a constant state of discord. ${ }^{10}$

The availability of oil, gas, coal and other natural resources, as well as emissions of harmful substances into the atmosphere, draw the attention of the world community to the state of their sovereign consumption, as well as their impact on neighboring countries and the planet as a whole.

In 2009, the BRICS members formed the Basic system to carry out coordinated activities to develop joint decisions on climate change issues. The proposal to harmonize the environmental legislation of the five countries, to clarify its goals, scope, depth and methods, to expand the competence of legal bodies and the Basic system site to include environmental issues is worth supporting. ${ }^{11}$ Actually, it is the

8 Каталано П. Главные цели и основания БРИКС: природа и история // Правовые аспекты БРИКС: Сборник докладов и выступлений на научном семинаре 8-9 сентября 2011 г. [Pierangelo Catalano, The Main Objectives and Bases of the BRICS: Nature and History in Legal Aspects of BRICS: Collection of Reports and Presentations at the Scientific Seminar, 8-9 September 2011] 13, 15 (T.A. Alekseeva \& P. Catalano (eds.), St. Petersburg: Publishing House of the Polytechnic University, 2011).

9 Бевеликова Н.М. БРИКС: правовые особенности развития // Журнал российского права. 2015. № 8. C. 110-123 [Nelly M. Bevelikova, BRICS: Legal Features of Development, 8 Journal of Russian Law 110 (2015)].

10 Боголюбов С.А. Суверенитет России на ее природные ресурсы // Lex Russica. 2016. № 6. C. 11-12 [Sergey A. Bogolyubov, Sovereignty of Russia over its Natural Resources, 6 Lex Russica 10, 11-12 (2016)].

11 Шорников Д.В. Пределы и особенности гармонизации экологического законодательства России и иных стран БРИКС // Правовые аспекты БРИКС: Сборник докладов и выступлений на научном семинаре 8-9 сентября 2011 г. C. 120 [Dmitry V. Shornikov, Limits and Features of Harmonization of Environmental Legislation of Russia and Other BRICS Countries in Legal Aspects of BRICS, supra note 8, at 116,120$]$. 
aim every modern environmentally-oriented state to create effective instruments for the legal protection of the environment and to ensure the right of every person to a favorable environment. Continuous international cooperation and improvement of national environmental legislation and the creation of international universal legal means of environmental protection are necessary to solve this problem. ${ }^{12}$

Comparative legal research of the environmental legislation of the BRICS countries has not received appropriate attention in Russian legal literature. Therefore, it is reasonable to research this topic to expand doctrinal ideas about foreign experience in the field of responsibility for environmental offenses and to use this experience to develop Russian environmental legislation.

Most contemporary research is devoted to the discussion of the legislation and judicial practice of the BRICS countries on environmental protection in general (works by S. Bogolyubov, ${ }_{13}^{13}$ A. Rozentsvayg ${ }_{1}^{14} \mathrm{~N}$. Khludeneva ${ }^{15}$ and others), without comparative analysis of the separate environmental-legal doctrines. At the same time, many researchers agree that the law, the state, and society, having proclaimed the environmental rights of citizens, should name bodies and officials responsible for upholding and protecting such rights. This tends to be the case, but a number of state responsibilities are indicated vaguely or declaratively - the conduct of the country's environmental policy directly depends on the performance of the appropriate duties of legal entities and individuals, since there can be no subjective law without a proper and adequate adherence to it, aimed at its fulfilment. ${ }^{16}$

12 Рыженков А.Я. Правовой опыт охраны окружающей среды в зарубежных странах: вопросы взаимовлияния // Бизнес. Образование. Право. Вестник Волгоградского института бизнеса. 2012. № 4(21). C. 237-241 [Anatoly Ya. Ryzhenkov, Legal Experience of Environmental Protection in Foreign Countries: Issues of Mutual Influence, 4(21) Business. Education. Law. Bulletin of the Volgograd Institute of Business 237 (2012)].

13 Боголюбов С.А. Соотношение экологических политик России и других государств // Экологическое право. 2016. № 4. C. 23-32 [Sergey A. Bogolyubov, The Correlation Between the Environmental Policies of Russia and Other States, 4 Environmental Law 23 (2016)].

14 Розенцвайг А.И. Развитие экологической политики в Российской Федерации на современном этапе // Право и экология: Материалы VIII Международной школы-практикума молодых ученыхюристов (Москва, 23-24 мая 2013 г.) [Anna I. Rozentsvayg, The Current Stage of Development of Environmental Policy in the Russian Federation in Law and Ecology: Materials of the $8^{\text {th }}$ International School of Practice of Young Scientists and Lawyers (Moscow, 23-24 May 2013)] 99 (Yu.A. Tikhomirov \& S.A. Bogolyubov (eds.), Moscow: IZiSP; Infra-M, 2014).

15 Хлуденева Н.И. Приоритеты государственной экологической политики и право // Право и экология: Материалы VIII Международной школы-практикума молодых ученых-юристов (Москва, 23-24 мая 2013 г.). C. 103-110 [Natalya I. Khludeneva, Priorities of the State Environmental Policy and Law in Law and Ecology, supra note 14, at 103].

16 Жаксыбекова Ф.С. Уголовная политика в борьбе с экологической преступностью в Республике Казахстан // Право и экология: Материалы VIII Международной школы-практикума молодых ученых-юристов (Москва, 23-24 мая 2013 г.). С. 142-145 [Farida S. Zhaksybekova, Criminal Policy in the Fight Against Environmental Crime in the Republic of Kazakhstan in Law and Ecology, supra note 14, at 142]. 
The purpose of this paper is to summarize the experience of the BRICS countries in the field of regulating responsibility for environmental offenses to make recommendations for improving the environmental legislation of the Russian Federation, as well as proposing successful regulatory solutions on the basis of Russian law for other BRICS countries taking into account their national peculiarities.

\section{Peculiarities of the Legislation of the BRICS Countries on Legal Liability for Environmental Offenses}

\subsection{Federative Republic of Brazil}

Brazilian environmental legislation is considered to be one of the most modern in the world. Article 225 of the Brazilian Constitution states that everyone has the right to a balanced environment (a balanced environment is required for a good quality lifestyle), which should equally be provided by the state and civil society. ${ }^{17}$

According to other constitutional provisions, the State promotes research and exploitation of mineral resources on a sustainable basis, i.e. taking into account environmental protection and improving the socio-economic conditions of researchers. Everyone has the right to utilize an environmentally balanced environment suitable for general use by people and necessary for a good quality lifestyle (Arts. 174, 225 of the Constitution of Brazil).

Brazil's key law in the field of environmental protection is the Environmental Policy Act No. 6.938, adopted on 31 August $1981 .^{18}$ The Act establishes the mechanism for the formation, fulfillment and protection of rights to use natural resources, and sets up a "National Council" governmental institution, subordinated to the Ministry of the Environment, the main task of which is to integrate the activities of three levels (federative, state and municipal) of power in the field of environmental protection.

This Act is aimed at coordinating the responsibilities of state bodies in the field of environmental management and does not affect the rights and obligations of citizens in the field of environmental protection, although the Constitution imposes the same obligation to protect the environment on the state as on its citizens. Brazil's environmental legislation provides for three types of legal liability: civil law, criminal law and administrative law. Civil liability in the field of environmental protection is governed by Law No. 7.347 regulating industrial activities in order to avoid environmental disasters, adopted in 1985. This responsibility occurs when the action or inaction of the offender caused any type of environmental damage. The result of such liability is the elimination of damage caused to the environment and injured third parties. ${ }^{19}$

17 Экологические положения конституций [The Environmental Provisions of Constitutions] 48-59 (E.A. Vystorobets (eds.), Moscow; Ufa: MiRmpOS, 2012).

18 Environmental Policy Act No. 6.938 of 31 August 1981 (Jan. 2, 2019), available at https://www.ecolex. org/details/legislation/environmental-policy-act-no-6938-lex-faoc012932/.

19 Law No. 7.347 of 24 July 1985 regulating industrial activities in order to avoid environmental disasters (Jan. 2, 2019), available at https://www.ecolex.org/details/legislation/law-no-7347-regulating-industrialactivities-in-order-to-avoid-environmental-disasters-lex-faoc025060/?q=No.+7.347+\%281985\%29. 
Paragraph 1 of Article 14 of the Brazilian Environmental Policy Act No. 6.938 states that

the polluter is obliged, regardless of whether it is guilty, to compensate for damage caused to the environment and to third parties injured by its activities.

Under paragraph 4 of Article 3 of the Environmental Policy Act, the term "polluter" should be understood to mean any individual or legal entity directly or indirectly responsible for the activity that led to environmental deterioration.

The principle of objective civil liability is also enshrined in Chapter 1 of Section 9 of the Brazilian Civil Code, which contains provisions on liability for damages. Article 927 of the Brazilian Civil Code provides that the obligation to pay for damage will exist regardless of fault in cases provided for by law, or when the activity performed by the person causing the harm entails a risk to the exercise of rights of others.

In other words, the legislator determined that civil liability aimed at compensating environmental damage does not require guilt (responsibility does not depend on guilt), and evidence of the existence of an action (omission) violating environmental law, and the cause and effect relationship between the damage and the action/ omission of the offender are sufficient grounds for the application of civil liability measures aimed at compensation for environmental damage. Brazilian environmental legislation also establishes the principle of joint and several liability. In accordance with Article 942 of the Civil Code, provided that the offense that caused the damage was committed by several persons, these persons should be liable jointly and severally for the compensation of environmental damage.

Administrative and legal responsibility for violations of environmental legislation is regulated by Decree No. 6.514, adopted on 22 July 2008. Environmental administrative and legal liability is based on the results of the actions or omissions of the offender that violated environmental legislation, regardless of the occurrence of actual environmental damage.

The following administrative penalties apply to offenders: a warning; a fine (up to 50 million reals); confiscation of illegal gains, as well as products and funds used to commit a crime; suspension of activity; closing of premises; demolition work; and restriction of rights. ${ }^{20}$

Law No. 9.605 on Environmental Crimes, adopted on 12 February 1998, establishes that criminal responsibility is personalized and applies not only to individuals but also to legal entities. Types of criminal punishment in the field of environmental management include: fines; temporary restrictions of rights; partial or full suspensions of activity; house arrest; and seizure of the instrument of the crime.

20 Decree No. 6.514 of 22 July 2008 establishing penalties and administrative offences for illegal activities against the environment (Jan. 2, 2019), available at https://www.ecolex.org/details/legislation/ decree-no-6514-establishing-penalties-and-administrative-offences-for-illegal-activities-againstthe-environment-lex-faoc109832/?q=6.514+\&xdate_min=\&xdate_max=. 
The question of specialized environmental courts has also been positively resolved in Brazil. The High Court of Brazil, which has already pronounced judgements on several thousand environmental cases, is the country's de facto environmental court. This led to its being referred to in academic literature as the Brazilian "Green Court," since it was praised by officials of the United Nations Environment Program (UNEP) and the International Union for the Conservation of Nature and Natural Resources (IUCN) for its transparency and innovation in the field of environmental law.

Over the past few years, the court has achieved great success in ensuring compliance with environmental legislation, demonstrating its deep understanding and awareness of environmental problems in the country. ${ }^{21}$

\subsection{Republic of India}

Article 48A of the Constitution of India states that

The state aims to protect and improve environmental conditions, to protect forests and wildlife of the country.

The Constitution also provides that one of the main responsibilities of every Indian citizen is to protect and improve forests, lakes, rivers, and wildlife (Art. $51 \mathrm{~A}(\mathrm{~d}))^{22}$

The right to a satisfactory and healthy environment is not directly enshrined in the Constitution of India but there are many provisions in the Constitution of India guaranteeing its fulfillment. In our opinion, this approach cannot be considered convincing from the point of view of the legal drafting standards and the priority of environmental protection tasks defined in the sectoral legislation of India. Therefore, it seems that it would be advisable to enshrine such a significant subjective right as the right to satisfactory and healthy environment in the Constitution of India as a separate provision and, in this respect, the experience of the constitutional entrenchment of environmental rights in Russia may be of interest to the Indian legislator.

The key documents in the field of environmental protection in India are two normative acts: the Environmental Protection Rules, adopted on 19 November 1986 (with subsequent amendments and additions) ${ }_{1}^{23}$ and the National Environmental Tribunal Act, adopted on 17 June 1995. ${ }^{24}$ In general, in India, the emphasis is on criminal liability, and the main sanctions are measures such as fines and imprisonment.

21 Nicholas S. Bryner, Brazil's Green Court: Environmental Law in the Superior Tribunal de Justiça (High Court of Brazil), 29(2) Pace Environmental Law Review 470, 475-476 (2012).

22 Конституции государств Азии. В 3 т. Т. 2: Средняя Азия и Индостан [The Constitutions of States in Asia. In 3 vol. Vol. 2: Central Asia and the Indian Subcontinent] 177-448 (Moscow: Institute of Legislation and Comparative Law under the Government of the Russian Federation; Norma, 2010).

23 The Ministry of Environment \& Forests, The Environment (Protection) Rules, 1986 (Jan. 2, 2019), available at http://www.envfor.nic.in/legis/env/env4.html.

24 The Ministry of Environment \& Forests, The National Environment Tribunal Act, 1995 (Jan. 2, 2019), available at http://www.envfor.nic.in/legis/others/tribunal.html. 
Thirty years ago, the Government of India developed and adopted an Action Plan on the Ganges - the "river of life" - establishing a central authority to purify its waters and reduce industrial, domestic and other anthropogenic pollution. The Supreme Court of India is responsible for supervision of the execution of environmental legislation. The Court has a Supervisory Committee and the Plenipotentiary Committee on Waste, coordinating and approving the activity of environmental and law enforcement agencies. ${ }^{25}$

In order to ensure environmental safety during the use of atomic energy in India, a commission on regulation of activities in the field of atomic energy has been established to ensure ionizing radiation and atomic energy does not damage the health of the population, the state or the people working in the nuclear industry.

Depending on the degree of the possible impact on health, registration and approval of technical passports for objects may be required, together with research of project documentation, including calculation of possible threats and consequent supervisory measures and inspections in accordance with the Safety Guidelines and the Code for the Safe Operation of atomic power stations, ${ }^{26}$ as well as a procedure and rules for decommissioning, liability for radiation pollution, and compensation of harm.

Issues of compensation for environmental damage are regulated in the National Green Tribunal Act of 2 June 2010, ${ }^{27}$ which is aimed at resolving disputes arising in connection with environmental protection and conservation of forests and other natural resources, and also to regulate the issues of ensuring and observing any legal rights related to the environment, and simplifying procedures for obtaining compensation for damage caused to persons and their property by environmental crime.

Article 17 of Chapter 3 of the Law on the National Green Tribunal stipulates that for causing death, damage to any person or his property, or damage to the environment, the owner (holder) is directly responsible for compensation based on the "polluter pays" principle.

At the same time, in cases of fatalities, injuries or damage caused by an accident, operations or processes where the adverse environmental impact of the enterprise's activities cannot be referred to any single activity, operation or process, but a combination of several such activities, the responsibility can be proportionally distributed among those who are responsible for the activity, operations and processes which led to the environmental offense.

25 Шейнин Л.Б. Органы охраны окружающей среды: необычный опыт Индии // Государственная служба. 2008. № 3. С. $72-76$ [Leonid B. Sheynin, Environmental Protection Authorities: The Unusual Experience of India, 3 Public Service 72 (2008)].

26 Крысенкова Н.Б. Обеспечение экологической безопасности объектов атомной отрасли в Индии // Право и экология: Материалы VIII Международной школы-практикума молодых ученых-юристов (Москва, 23-24 мая 2013 г.). С. 344-349 [Natalya B. Krysenkova, Ensuring Environmental Safety of Nuclear Facilities in India in Law and Ecology, supra note 14, at 344].

27 The Ministry of Environment \& Forests, The National Green Tribunal Act of India, 2010 (Jan. 2, 2019), available at http://www.moef.nic.in/downloads/public-information/NGT-fin.pdf. 
In addition, the law also provides for the establishment of a special court called the National Green Tribunal, whose activities are aimed at resolving environmental disputes, as well as reducing the burden of litigation.

\subsection{People's Republic of China}

The regulatory framework in the field of China's environmental protection is formed by the PRC Law on Environmental Protection, and special laws on Water, on the Protection of Wild Fauna and on Land Management. The key legislation in the field of environmental protection is the Law of the People's Republic of China on Environmental Protection adopted on 26 December 1989 (with amendments and additions dated 24 April 2014, which came into effect on 1 January 2015).

Chapter 1 of the PRC Constitution (Art. 26) establishes state protection of the environment in which people live, and the duty of the state to prevent and control environmental pollution and violations in the field of environmental management. ${ }^{28}$ There is no article containing the right of citizens to a favorable environment in the second chapter on regulation of the basic rights and duties of citizens. In our opinion, the existence of such a right in the Constitution of any country should be binding. The main responsibilities in the field of environmental protection are contained in Article 6 of the Law on Environmental Protection.

These include: the raising of environmental awareness; maintaining an energy-saving lifestyle; and conscientious fulfillment of environmental protection duties. Legal responsibility issues are given in Chapter 6 of the Law. Measures of administrative responsibility of the legislative bodies of the People's Republic of China include sanctions such as fines (Arts. 59, 61, 62); suspension of activities (Arts. 60, 61); detention (Art. 63); reprimands, severe reprimands, demotion, and removal from office (Art. 68).

Those who damage through pollution and environmental degradation bear tort liability in accordance with the provisions of the Tort Law of the People's Republic of China, adopted on 26 December 2009 and came into effect on 1 July 2010. ${ }^{29}$ The mechanism of compensation for environmental damage in China is enshrined in Article 64 of Chapter 6 of the Environmental Protection Law of People's Republic of China and in Chapter 8 of the Tort Law of the People's Republic of China.

Therefore, in accordance with the Law on Tort Liability, a person who damages the environment or, as a result of committing an environmental offense, damages the life, health or property of people, must bear the tort liability. In the event of any dispute concerning environmental pollution, the polluter directly assumes the burden of proof in matters of his involvement in the subject of the dispute (that is,

28 Constitution of the People's Republic of China, 4 December 1982 (Jan. 2, 2019), available at https:// china.usc.edu/constitution-peoples-republic-china-1982\#preamble.

29 Tort Law of the People's Republic of China, 26 December 2009 (Jan. 2, 2019), available at http://www. wipo.int/edocs/lexdocs/laws/en/cn/cn136en.pdf. 
it is legitimate to talk about the presumption of the polluter's fault), the existence of a cause and effect relationship between his behavior and the caused harm, as well as in matters of responsibility for environmental offenses or reduction of liability in certain circumstances (in case of the mitigating circumstances specified in Chapter 3 to which the legislator refers: conditions under which the injured party is also guilty of causing damage; intentional damage by the victim; damage caused by force majeure; and damage caused by the need for such behavior or self-defense).

As for criminal liability, Article 69 of the Law of the People's Republic of China on Environmental Protection provides that violation of this Law is a criminal offense and can be investigated in accordance with the law on criminal liability. ${ }^{30}$ The Law provides for distribution of liability for committing environmental offenses if there are two or more offenders.

Such distribution depends on various factors, including the type and amount of pollutants emitted by a particular polluter. In addition, the Law establishes that, for damage to health or property caused as a result of environmental pollution, the polluter is jointly and severally liable with the third party, even if this damage was caused by the fault of the third party. This rule gives victims the right to choose from whom exactly to seek compensation for environmental damage because, in situations where the damage is caused by a third party, the affected party may claim compensation from either the polluter or the third party.

The Law also allows the polluter and a third party to decide independently among themselves on matters relating to compensation for environmental harm. If the affected party prefers to seek compensation for environmental damage from the polluter, then the polluter may subsequently demand compensation from a third party for this. In the PRC, there is no special judicial body that deals with cases of bringing offenders to justice for environmental offenses. These offenses are considered by the courts of general jurisdiction, as is the case in Russia.

\subsection{Republic of South Africa}

As in all previous countries considered in this article, the South African Constitution (in Article 24) provides for the right of everyone to an environment that is not harmful to their health, as well as for the protection of the environment for the benefit of present and future generations, and for the adoption of reasonable legislative and other measures to prevent pollution of nature and environmental degradation. ${ }^{31}$ The key South African law in the field of environmental protection is Law No. 107 on Environmental Protection, adopted on 27 November 1998. The Preamble of the Law

30 Environmental Protection Law of the People's Republic of China, 1 January 2015 (Jan. 2, 2019), available at https://www.chinadialogue.net/Environmental-Protection-Law-2014-eversion.pdf.

31 Constitution of the Republic of South Africa, as adopted on 8 May 1996 and amended on 11 October 1996 by the Constitutional Assembly (Jan. 2, 2019), available at http://www.justice.gov.za/legislation/ constitution/SAConstitution-web-eng.pdf. 
sets out the basic rights of citizens in the field of environmental protection. The Law establishes that everyone has the right to live in a protected environment for the benefit of present and future generations, the right to prevent pollution and environmental degradation, and the right to promote conservation. The Law also requires safe, environmentally sustainable development and use of natural resources.

The main responsibilities for the compensation of environmental damage are spelled out in Article 28 (Chapter 7) of the National Environmental Management Act of 1998. These include the adoption of reasonable measures to prevent pollution and continuing or repeated environmental degradation. ${ }^{32}$

Under the term "reasonable measures," South African lawmakers understand research, analysis and assessment of the impact on the environment, the timely awareness of employees (the Department of Environment and Tourism) of environmental risks, measures aimed at terminating, altering or controlling any actions of an activity or process causing pollution or environmental degradation, measures to prevent the movement of pollutants, measures to eliminate the source of pollution or degradation and, measures designed to eliminate the effects of pollution and environmental degradation. Legal liability for offenses in the field of environmental protection in South Africa does not have the usual division of administrative, criminal, property and disciplinary responsibility as in Russian legislation. However, in the Republic of South Africa there is Corporate Social Responsibility (hereinafter CSR), which is commonly understood as the duty to conduct business ethically and to contribute to economic development, improving the quality of life of workers and their families, as well as society as a whole. One of the main goals of CSR is to maintain natural resources and environmental programs to protect and preserve natural habitats and to create information openness for people about the world around them.

Types and penalties for violations of environmental legislation are contained in various regulatory acts of South Africa and include fines and imprisonment. For example, fines are referred to in Articles 67 and 68 of the National Environmental Management Waste Act of 2008, in the Atmospheric Pollution Prevention Act of 1965 and in Article 24 of the National Environmental Management Act. In the system of government bodies in South Africa, as well as in China and Russia, there is no specialized court authorized to bring those who are guilty of environmental offenses to legal responsibility.

\subsection{Legal Regulation of Legal Responsibility for Environmental Law Violations in the Russian Federation}

Article 42 of the Constitution of the Russian Federation enshrines the right of everyone to a favorable environment, reliable information about the state of the

32 National Environmental Management Act, 1998 (Jan. 2, 2019), available at https://www.environment. gov.za/sites/default/files/legislations/nema_amendment_act107.pdf. 
environment and to compensation for harm caused to the health and/or property of a citizen by an environmental offense. The main law in the field of environmental protection in the Russian Federation is Federal law of 10 January 2002 No. 7-FZ "On Environmental Protection." Article 11 of this Law enshrines the basic rights and obligations of citizens in the field of nature preservation.

The environmental legislation of the Russian Federation provides for the following types of liability for offenses in the field of environmental protection: civil law (property); disciplinary; administrative; and criminal. ${ }^{33}$ Understanding the subjectmatter and legal nature of civil liability is very important for the formation of effective legal measures for compensation for, and protection from, harm.

Current Russian law does not refer to the term "environmental damage," however, in paragraph 1 of Article 79 of the Federal law "On Environmental Protection" the right to compensation for harm caused to the health of citizens by the negative impact of the environment as a result of economic or other activities of legal entities or individuals. Therefore, any environmental harm to health is subject to compensation, and not just harm caused by environmental offenses.

The category of "environmental harm" has received an ambiguous assessment in legal science; academics usually refer to damage caused to the environment. Environmental harm is considered any deterioration of the state of the environment due to a violation of legal environmental requirements. Harm primarily manifests itself in the form of environmental pollution, spoilage, destruction, damage, depletion of natural resources, and destruction of ecological systems. ${ }^{34}$

V. Petrov subdivided environmental harm into economic (that is, directly encroaching on the property interests of nature users, including owners), ecological (affecting the ecological interests of society in a clean, healthy, productive, genetically diverse natural habitat) and anthropological (encroaching on human health and the state of future generations). ${ }^{35}$

The Constitutional Court of the Russian Federation included environmental damage, damage to human health (social damage), and damage to private and public property (economic damage) under damage caused by an environmental offense. ${ }^{36}$

33 Федеральный закон от 10 января 2002 г. № 7-Ф3 «Об охране окружающей среды» // Собрание законодательства РФ. 2002. № 2. Ст. 133 [Federal Law No. 7-FZ of 10 January 2002. On Environmental Protection, Legislation Bulletin of the Russian Federation, 2002, No. 2, Art. 133].

34 Бринчук М.М. Экологическое право: Учебник [Mikhail M. Brinchuk, Environmental Law: Textbook] (Legal reference system "ConsultantPlus," 2008).

35 Петров В.В. Правовая охрана природы в СССР: Учебник [Vladislav V. Petrov, Legal Protection of Nature in the USSR: Textbook] 151-154 (Moscow: Yuridicheskaya literatura, 1984).

36 Постановление Конституционного Суда РФ от 2 июня 2015 г. № 12-П «По делу о проверке конституционности части 2 статьи 99, части 2 статьи 100 Лесного кодекса Российской Федерации и положений Постановления Правительства Российской Федерации «Об исчислении размера вреда, причиненного лесам вследствие нарушения лесного законодательства» в связи с жалобой общества с ограниченной ответственностью «Заполярнефть»» [Resolution of the Constitutional 
On this basis, environmental harm is any environmental degradation due to environmental violations, including pollution, depletion, damage, destruction, irrational use of natural objects, and degradation and destruction of ecological systems, natural sites and landscapes. The result of this can be the derogation of the material and non-material benefits protected by law, including the life and health of people, and the property of individuals and legal entities.

From the point of view of Russian scientific doctrine and legislation, according to the criterion of an object, environmental harm is of two kinds: harm caused to the environment and harm caused to the life, health and property of citizens. General rules for the compensation of environmental harm are regulated by Section 59 of the Civil Code of the Russian Federation "Obligations Arising due to the Causing of Harm," and special rules are prescribed by Articles 77-79 of the Federal law "On Environmental Protection," Article 69 of the Water Code of the Russian Federation, Article 100 of the Forest Code of the Russian Federation, Article 51 of the Law of the Russian Federation "On Minerals" and others.

Environmental damage can be caused by both legal and illegal actions. Article 77 of the Federal law "On Environmental Protection"imposes an obligation on business entities to compensate for environmental harm caused by an activity that is deemed responsible by a state expert examination.

Disciplinary responsibility is applied to persons whose duties include direct compliance with environmental legislation, as well as for non-compliance or improper performance by an employee of his official duties. The Labor Code provides for a number of disciplinary measures, i.e. warning, reprimand and dismissal.

Meanwhile, as A. Ryzhenkov noted, employees are brought to disciplinary responsibility for disciplinary misconduct, that is, non-performance or improper performance by the employee of assigned duties through his fault. This means that employees are brought to disciplinary responsibility not for a violation of environmental law but for a violation of labor law. There are no "environmental" disciplinary offenses. Therefore, this type of legal responsibility for environmental offenses should be excluded from Article 75 of the Federal law "On Environmental Protection. ${ }^{137}$ In our opinion, this conclusion is correct.

Administrative responsibility occurs for violations of the provisions of environmental law (by an individual or legal entity) and is regulated by Chapter 8 of the Code of Administrative Violations of the Russian Federation. The main types of

Court of the Russian Federation No. 12-P of 2 June 2015. On the Review of the Constitutionality of Part 2 of Article 99, Part 2 of Article 100 of the Forest Code of the Russian Federation and Provisions of the Order of the Government of the Russian Federation "On Calculation of the Size of the Harm Done to Forests Owing to Violation of the Forest Legislation" in Connection with the Complaint of Limited Liability Company "Zapolyarneft"] (Jan. 2, 2019), available at http://www.consultant.ru/document/ cons_doc_LAW_180575/.

37 Рыженков А.Я. Принципы экологического права [Anatoly Ya. Ryzhenkov, The Principles of Environmental Law] 108 (Moscow: Yurlitinform, 2018). 
administrative penalties in the field of environmental protection include: warnings; fines; administrative suspension of activity; confiscation of the instrument used to commit an offense; confiscation of products of an illegal nature; and deprivation of special rights.

Criminal liability arises as a result of an environmental crime, which should be understood as a socially dangerous act, committed in the form of an action or omission that has a negative impact upon the state of the environment, ecological systems and the components thereof. Punishments for criminal liability include: fines, compulsory work, forced labor, deprivation of the right to occupy certain positions and engage in certain activities, and the deprivation of liberty. ${ }^{38}$ Therefore, in Russia, as in other BRICS countries, we see a system of various types of legal responsibility for environmental offenses, and the absence of a special court that could consider such cases.

\section{Suggestions for Improving Legal Responsibility for Environmental Offenses in the Context of the BRICS Experience}

Russia is a fully-fledged part of the world community and contributes to environmental protection at the international and national levels. At the same time, the lack of effective organizational mechanisms in the field of environmental preservation in some cases does not allow implementation of the principle of inevitability of responsibility and thereby actually neutralizes the effect of establishing a broad range of legal sanctions.

It seems that an important role in solving this problem could be played by the exchange of experience in the formation of environmental legal awareness among representatives of the environmental and legal science of the BRICS countries, which would not only develop an understanding of legislative technologies and law enforcement experience, but also help identify the influence of the population's mentality on the perception of environmental legal information.

It seems necessary that, following the example of Brazil, Russia create a government agency (for example, in the form of the National Ecological Council (NEC)), subordinated to the Ministry of Natural Resources and Ecology of the Russian Federation, whose main task would be to coordinate the activities of two levels (federal and local) in the field of environmental protection, the synthesis of practical experience, and the development of proposals for improving the mechanism of compensation of environmental harm caused to the health and property of a citizen.

The status of this body should be regulated by the regulations of the Ministry of Natural Resources and Environment of the Russian Federation. It is also necessary

38 Уголовный кодекс Российской Федерации 13 июня 1996 г. № 63-Ф3 // Собрание законодательства РФ. 1996. № 25. Ст. 2954 [Criminal Code of the Russian Federation No. 63-FZ of 13 June 1996, Legislation Bulletin of the Russian Federation, 1996, No. 25, Art. 2954]. 
to oblige each constituent entity the Russian Federation and each federal district of Russia to submit annual reports to the NEC on the dynamics of the state of the environment, statistics on environmental offenses, data on compensation for environmental harm and other information. It is equally reasonable to use the positive experience of India in the field of setting up a specialized environmental court. In Russia, it would be advisable to organize a judicial panel (on environmental and natural resources disputes) as part of the Supreme Court of the Russian Federation, whose main task would be to resolve environmental and natural resources issues at the regional and federal levels. Today, in view of the high workload, the courts of general jurisdiction and the magistrate courts are increasing the time limits for the consideration of cases, which entails a number of negative consequences.

Specialized courts are narrowly specialized judicial bodies that have a special subject of litigation. These courts consider categories of cases that need a specialized approach. Consideration of cases in specialized courts presupposes a higher qualification of judges in certain branches of law, a uniform application of legislation, and a reduction of the number of judicial errors. As M. Kuchina notes, the need to create specialized courts is due to the desire to solve an extremely important state task, i.e. to increase the efficiency of judicial power. ${ }^{39}$

The system of specialized courts contributes to the formation of less costly, faster and more efficient legal proceedings, and one of the reasons for the undoubted merits of setting up specialized courts is the increase in accuracy in the adjudication of specialized cases. ${ }^{40}$ Federal Constitutional Law of 31 December 1996 No. 1-FKZ "On the Court System of the Russian Federation" ${ }^{\prime \prime 1}$ secured specialized courts in the system of federal courts of general jurisdiction and specialized arbitration courts that make up the system of federal arbitral courts.

According to Article 26 of this Law, specialized federal courts for considering civil and administrative cases, jurisdictional courts of general jurisdiction, as well as arbitration courts that consider business-related disputes and other cases, are established by amending and supplementing this Federal Constitutional Law.

Recently, a new specialized judicial body emerged among arbitration courts, i.e. a court specializing in resolving disputes related to the violation of intellectual property and related rights. The idea of creating such a court was discussed back in the

39 Кучина М.С. Специализированные суды: зарубежный опыт и перспективы развития в России // Российский следователь. 2017. № 13. С. 53-56 [Maria S. Kuchina, Specialized Courts: Foreign Experience and Prospects of Development in Russia, 13 Russian Investigator 53 (2017)].

40 Приженникова А.Н. Перспективы развития специализированных судов в России // Юридические исследования. 2014. № 6. С. 117 [Alyona N. Prizhennikova, Prospects of Development of the Specialized Courts in Russia, 6 Legal Research 116, 117 (2014)].

41 Федеральный конституционный закон от 31 декабря 1996 г. № 1-ФК3 «О судебной системе Российской Федерации» // Собрание законодательства РФ. 1997. № 1. Ст. 1 [Federal Constitutional Law No. 1-FKZ of 31 December 1996. On the Court System of the Russian Federation, Legislation Bulletin of the Russian Federation, 1997, No. 1, Art. 1]. 
late 80 s and early 90 s of the last century. On 6 December 2011, Federal Constitutional Law No. 4-FKZ "On Amendments to the Federal Constitutional Law 'On the Court System of the Russian Federation' and the Federal Constitutional Law'On Arbitration Courts in the Russian Federation' in Connection with the Creation in the System of Arbitration Courts of the Court of Intellectual Rights" was published and came into force. ${ }^{42}$ The Court of Intellectual Rights began to consider cases on 3 July 2013, as determined by the Resolution of the Plenum of the Supreme Arbitration Court of the Russian Federation. ${ }^{43}$ The need to create this court was due to the complexity, and increase in the number, of cases in the field of intellectual rights. In this court, cases are considered in the first and cassation instances.

According to experts, the work of the court on intellectual property rights was recognized as effective and expedient. ${ }^{44}$

As indicated by D. Danielyan, the formation of the first specialized court in the system of arbitration courts required the specialization of judges to be taken into account and entailed the establishment of special procedures, and a change in the organizational aspects of the activity and interaction of the new court within the existing courts, i.e. a systematic approach to the development of the entire judicial system and the system of arbitration courts in particular. ${ }^{45}$

Similar judicial bodies operate in Austria (Patent Court), Germany (Federal Patent Court), Thailand (Intellectual Property Court) and other countries. There are legal prerequisites for setting up specialized courts to deal with environmental and natural resources disputes in Russia. Their introduction will make the process of considering environmental and natural resources cases more qualified and efficient. We believe that judges in environmental and natural resource courts (courts of general jurisdiction) will narrowly specialize in resolving disputes arising in the field

42 Федеральный конституционный закон от 6 декабря 2011 г. № 4-ФК3 «О внесении изменений в Федеральный конституционный закон «О судебной системе Российской Федерации» и Федеральный конституционный закон «Об арбитражных судах в Российской Федерации» в связи с созданием в системе арбитражных судов Суда по интеллектуальным правам» // Российская газета. 2011. № 278 [Federal Constitutional Law No. 4-FKZ of 6 December 2011. On Amendments to the Federal Constitutional Law "On the Court System of the Russian Federation" and the Federal Constitutional Law "On Arbitration Courts in the Russian Federation" in Connection with the Creation in the System of Arbitration Courts of the Court of Intellectual Rights, Rossiyskaya Gazeta, 2011, No. 278].

43 Постановление Пленума ВАС РФ от 2 июля 2013 г. № 51 «О начале деятельности Суда по интеллектуальным правам» [Resolution of the Plenum of the Supreme Arbitration Court of the Russian Federation No. 51 of 2 July 2013. On the Beginning of the Activities of the Court on Intellectual Property Rights] (Jan. 2, 2019), available at http://www.consultant.ru/document/cons_doc_LAW_149167/.

44 Кистринова О.В. Специализированные суды: опыт России и зарубежных стран // Российский судья. 2015. № 2. С. 11 [Olga V. Kistrinova, Specialized Courts: The Experience of Russia and Foreign Countries, 2 Russian Judge 9, 11 (2015)].

45 Даниелян Д.Р. К вопросу о специализации судов в организации аппарата судебной власти России // Мировой судья. 2013. № 7. С. 20-21 [Daniel R. Danielyan, On Specialization in the Organization of the Apparatus of the Judiciary of Russia, 7 Justice of the Peace 19, 20-21 (2013)]. 
of environmental and natural resource law, and the presence of special knowledge in this area will be a mandatory criterion for their appointment to the post. ${ }^{46}$

With such a dispute resolution system, there will be a significant reduction in costs. This will also ensure the uniformity of judicial practice in environmental and natural resources disputes, which will enable the parties to predict the likely outcome of a case based on a previous decision and established judicial practice. The presence of a special court will also provide an opportunity to expand the subject matter of the trial, especially for lawsuits arising from public interest, for participation in the process by interested third parties, for commencement of a class action, etc. ${ }^{47}$ The issue of the timing of the consideration of environmental and natural resources disputes will also be resolved.

In turn, the experience of Russian regulation of environmental relations (including in the field of legal liability for environmental offenses) could also be of interest to other BRICS countries.

For example, in Russia, as well as in Brazil and South Africa, the constitutional right of everyone to a favorable environment is enshrined in law and directly guaranteed by the state.

However, in India there is no rule directly regulating the right of everyone to a favorable environment, which is an omission that needs to be rectified. China's Constitution also lacks any provision guaranteeing the right of citizens to a favorable environment but it does establish the obligation of the state to protect the environment. Furthermore, the provisions of Russian environmental legislation that regulate civil (property) liability for environmental offenses may be of interest to the other BRICS countries in terms of procedures for compensation for lawful harm, as well as the three-tiered system of the structure of environmental harm (economic, environmental and social) that was formulated by scientific doctrine (and adopted by the legislator) and its practical importance for calculating the amount of compensation. Structures of individual parts of the Criminal Code of the Russian Federation (Article 358"Ecocide") or administrative sanctions (administrative suspension of environmentally hazardous activities) can be very useful in practice.

\section{Conclusion}

The above study of the environmental legislation of the BRICS countries reveals a number of general and specific directions in environmental policy by way of which they could enrich each other with positive experience, overcome difficulties in the organization of environmental management and environmental protection, and prevent possible errors in the context of global economic and environmental crises, making recommendations for environmental improvement.

\footnotetext{
46 Gitanjali N. Gill, A Green Tribunal for India, 22(3) Journal of Environmental Law 461, 468 (2010).

47 Harry Woolf, Are the Judiciary Environmentally Myopic?, 4(1) Journal of Environmental Law 1, 4-5 (1992).
} 
Improving the legislation of the BRICS countries in the field of legal liability for environmental offenses by taking into account the positive experience of these countries will help to increase the effectiveness of prevention and rectification of the consequences of events that have a negative impact on the environment of both the Russian Federation and the BRICS association as a whole. Consequently, a comparative legal analysis of the peculiarities and specifics of national environmental legislation in BRICS countries suggests that the general principles of responsibility for environmental offenses are inherent in all these countries, despite their fundamental differences in history, culture and geographical location.

In order to improve the mechanisms for the protection of the environment, property and citizens' health from the consequences of environmental offenses, it is important to continuously coordinate the environmental policies of the BRICS countries, the goals of which are to ensure the rights of each person, effective international cooperation, the creation of legal and economic mechanisms that stimulate determination of the procedure for compensation for environmental harm, and consideration of natural, national, legal, social and other features of the BRICS countries. In this article, we carried out a comparative analysis of the environmental legislation of the BRICS countries according to two main criteria. The first criterion was to identify the presence in the state of specialized bodies that deal with cases of bringing violators of environmental legislation to legal responsibility. We have established that in the BRICS countries there is no single body of executive authority that would be responsible for investigating and making decisions on bringing to offenders to responsibility for environmental offenses.

These functions are performed by various public authorities, although the coordinating function of the Brazilian National Council at the Ministry of the Environment is of great interest to Russia. At the same time, we believe that the creation of a single such body would allow for a more efficient and effective consideration of issues related to environmental protection and the use of natural resources, including ensuring the rights of citizens and legal entities to compensate for environmental harm. Of particular interest to Russia is the experience of creating a specialized court that deals with cases in the field of environmental protection and the use of natural resources. And although many organizational and procedural issues of creating such a court require additional discussions, the experience of India, where a specialized environmental court (the National Green Tribunal) has been operating for many years, as well as Brazil, where the High Court of Brazil resolves environmental disputes, deserves special attention.

At the same time, it appears that this experience may be of interest not only to Russia, but also to the People's Republic of China and South Africa, where specialized environmental courts are also absent, which reduces the effectiveness of nature preservation measures.

The second criterion was the analysis of the legal technique of securing the environmental rights of citizens in the constitutions and legislation of the BRICS 
countries. We concluded that the constitutions of India and China may be interested in the wording of Article 42 of the Constitution of Russia regarding the environmental rights of citizens. All the BRICS countries will be interested in the unusual type of responsibility (CSR) enshrined in South African law.

Our analysis provided a high-level assessment of the environmental legislation of the BRICS countries, some of whose provisions (if implemented in Russian law) would allow the system of legal liability in the Russian Federation for environmental offenses to be improved, and make it more modern and efficient.

\section{Acknowledgments}

The paper was written with support of the Volgograd Institute of Management branch of Russian Academy of National Economy and Public Administration under the President of the Russian Federation in the framework of research project No. 032018 VIM.

\section{References}

Bryner N.S. Brazil's Green Court: Environmental Law in the Superior Tribunal de Justiça (High Court of Brazil), 29(2) Pace Environmental Law Review 470 (2012).

Gill G.N. A Green Tribunal for India, 22(3) Journal of Environmental Law 461 (2010).

Woolf H. Are the Judiciary Environmentally Myopic?, 4(1) Journal of Environmental Law 1 (1992).

\section{Information about the authors}

Aleksey Anisimov (Volgograd, Russia) - Professor, Department of Constitutional and Administrative Law, Volgograd Institute of Management - Branch of the Russian Academy of National Economy and Public Administration under the President of the Russian Federation (8 Gagarina St., Volgograd, 400131, Russia; e-mail: anisimovap@ mail.ru).

Julia Kayushnikova (Volgograd, Russia) - Deputy Dean of the Law Faculty, Volgograd Institute of Management - Branch of the Russian Academy of National Economy and Public Administration under the President of the Russian Federation (8 Gagarina St., Volgograd, 400131, Russia; e-mail: kayshnikova@yandex.ru). 